\title{
Sporothrix schenckii COMPLEX: SUSCEPTIBILITIES TO COMBINED ANTIFUNGAL AGENTS AND CHARACTERIZATION OF ENZYMATIC PROFILES
}

Daniele Carvalho OLIVEIRA(1,2), Érico Silva de LORETO(1,2), Débora Alves Nunes MARIO(2,3), Paulo G. Markus LOPES(3), Louise Vignolles NEVES(2), Marta Pires da ROCHA(2), Janio Morais SANTURIO(1,2) \& Sydney Hartz ALVES(1,2,3)

\begin{abstract}
SUMMARY
Sporothrix schenckii was reclassified as a complex encompassing six cryptic species, which calls for the reassessment of clinical and epidemiological data of these new species. We evaluated the susceptibility of Sporothrix albicans $(\mathrm{n}=1), S$. brasiliensis $(\mathrm{n}=6)$, S. globosa $(\mathrm{n}=1)$, . mexicana $(\mathrm{n}=1)$ and $S$. schenckii $(\mathrm{n}=36)$ to terbinafine $(\mathrm{TRB})$ alone and in combination with itraconazole (ITZ), ketoconazole (KTZ), and voriconazole (VRZ) by a checkerboard microdilution method and determined the enzymatic profile of these species with the API-ZYM kit. Most interactions were additive $(27.5 \%, 32.5 \%$ and $5 \%)$ or indifferent $(70 \%, 50 \%$ and $52.5 \%$ ) for TRB+KTZ, TRB+ITZ and TRB+VRZ, respectively. Antagonisms were observed in $42.5 \%$ of isolates for the TRB+VRZ combination. Based on enzymatic profiling, the Sporothrix schenckii strains were categorized into 14 biotypes. Leucine arylamidase (LA) activity was observed only for $S$. albicans and $S$. mexicana. The species $S$. globosa and $S$. mexicana were the only species without $\beta$-glucosidase (GS) activity. Our results may contribute to a better understanding of virulence and resistance among species of the genus Sporothrix in further studies.
\end{abstract}

KEYWORDS: Sporothrix; Combination therapy; Susceptibility; Enzymatic profile; Antifungal agents.

\section{INTRODUCTION}

Sporotrichosis is caused by the dimorphic fungus Sporothrix schenckii, which is one of the predominant microorganisms responsible for cutaneous and lymphocutaneous mycosis, affecting both humans and animals. Sporotrichosis has a worldwide distribution, especially in tropical and subtropical regions of Latin America where endemic areas have been recognized ${ }^{2,5}$. Furthermore, an increase in the frequency of sporotrichosis as an opportunistic disease has been observed in the past few years, and this increase is associated with significant morbidity and mortality rates in immunocompromised patients ${ }^{5,10}$.

For many years, local hyperthermia and oral potassium iodide solution have been therapeutic options for the treatment of sporotrichosis ${ }^{21,22}$. Additionally, with over 50 years of clinical use, amphotericin B (AMB) is still considered the "gold standard" for the treatment of serious fungal infections. However, the use of AMB is associated with significant adverse effects related to toxicity ${ }^{13}$. According to the Clinical Practice Guidelines for the Management of Sporotrichosis ${ }^{13}$, monotherapy with itraconazole is the first choice for subcutaneous sporotrichosis treatment. Although treatment with itraconazole has been shown to elicit an excellent therapeutic response in humans ${ }^{4}$, reports of sporotrichosis refractory to oral itraconazole treatment have been described, particularly in animals ${ }^{11}$.
In vitro susceptibility studies for terbinafine have been encouraging ${ }^{2,18}$, and studies using terbinafine with human patients have shown good efficacy ${ }^{9}$. Additionally, cases of refractory and disseminated sporotrichosis have been treated with a combination of antifungal drugs, presenting satisfactory results ${ }^{6,11}$.

Recently, it was proposed that Sporothrix schenckii is a species complex encompassing six cryptic species ${ }^{15}$, which calls for the reassessment of clinical and epidemiological data, in particular with regard to antifungal susceptibility and phenotypic characteristics which may be related to virulence ${ }^{3,16,17}$. In this context, the aim of this study was to evaluate the in vitro susceptibility of Sporothrix albicans, $S$. brasiliensis, S. globosa, S. mexicana and S. schenckii to terbinafine in combination with itraconazole, ketoconazole or voriconazole, as well as the enzymatic profile of these species.

\section{MATERIAL AND METHODS}

Microorganisms: Thirty-eight isolates obtained from human $(\mathrm{n}=30)$ and feline $(n=8)$ cases of sporotrichosis diagnosed in the hinterland of Rio Grande do Sul State (Brazil). These strains were maintained in the Department of Microbiology of the Federal University of Santa Maria and were previously identified by phenotypic and molecular tests ${ }^{17}$ as $S$. 


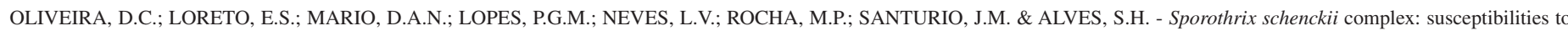
combined antifungal agents and characterization of enzymatic profiles. Rev. Inst. Med. Trop. Sao Paulo, 57(4): 289-94, 2015.

schenckii $(\mathrm{n}=36)$, S. albicans $(\mathrm{n}=1)$, and $S$. brasiliensis $(\mathrm{n}=6)$. The species S. globosa (CBS 132922) and S. mexicana (CBS 120341) were also included.

Antifungal drugs, in vitro susceptibility and drug interactions test: The antifungal agents itraconazole (ITZ), ketoconazole (KTZ) (ITZ and KTZ: Janssen Pharmaceutica, Beerse, Belgium), terbinafine (TRB) (Novartis, Basel, Switzerland) and voriconazole (VRZ) (Pfizer, Rome, Italy) were obtained commercially. Susceptibility tests were performed according to the CLSI protocol M38-A2 microdilution technique ${ }^{7}$, with filamentous phase of Sporothrix strains. Aspergillus flavus (ATCC 204304) was included as a control strain. Drug interactions were evaluated by the checkerboard method ${ }^{20}$, and the fractional inhibitory concentration (FIC) was calculated for each agent by dividing the minimal inhibitory concentration (MIC) of each drug in combination by the MIC of the drug alone. When computing the FIC index, off-scale MICs were converted to the next highest concentration.

FIC values were then summed up to determine the fractional inhibitory concentration index (FICI) resulting from the combination. Synergism was defined as FICI $\leq 0.5$ and additionally as $0.5<\mathrm{FICI} \leq 1.0$. Indifference was defined as $1.0<\mathrm{FICI} \leq 4$, whereas antagonism was defined as FICI $>4^{12}$.

Enzymatic profile: Enzymatic activity was determined using the API$\mathrm{ZYM}^{\circledR}$ commercial kit system (BioMérieux, Marcy-l'Étoile, France) in accordance with the manufacturer's instructions. The kit consists of 19 enzymatic substrates: alkaline phosphatase (KP), esterase (ES), esterase lipase (EL), lipase (LP), leucine arylamidase (LA), valine arylamidase (VA), cystine arylamidase (CA), trypsin (TR), $\alpha$-chymotrypsin $(\mathrm{CH})$, acid phosphatase (AP), naphthol-AS-BI-phosphohydrolase (NP), $\alpha$-galactosidase (GL), $\beta$-galactosidase (GA), $\beta$-glucuronidase (GU), $\alpha$-glucosidase (GC), $\beta$-glucosidase (GS), $N$-acetyl- $\beta$-glucosaminidase (NG), $\alpha$-mannosidase (MN) and $\alpha$-fucosidase (FU).

To prepare a conidia suspension with a turbidity of 5-6 McFarland in API suspension medium $(2 \mathrm{~mL}), 65 \mu \mathrm{L}$ of liquid phase from incubated cultures was added to each cupule of the APY-ZYM ${ }^{\circledR}$ tray and maintained at $37^{\circ} \mathrm{C}$ for four h. Tests were carried out in triplicate, and subsequently the enzymatic activities of all strains were analyzed, and results of the reactions were recorded. Interpretation of the results was based on the production and intensity of color development: 0 corresponded to a negative reaction, 5 to a reaction of maximum intensity and values 1 , 2,3 , and 4 were intermediate reactions with varying levels of intensity; however, according to the kit, reactions are only considered positiveintermediate when intensities are 3 and 4.

\section{RESULTS}

The results of the in vitro susceptibility test, FIC index, and the resulting drug interactions against the 40 Sporothrix sp. isolates are described in Table 1. MICs ranged from 0.03 to $0.5 \mu \mathrm{g} / \mathrm{mL}$ for TRB, 0.06 to $4.0 \mu \mathrm{g} / \mathrm{mL}$ for KTZ, 0.03 to $>128 \mu \mathrm{g} / \mathrm{mL}$ for ITZ and 1.0 to 16 $\mu \mathrm{g} / \mathrm{mL}$ for VRZ. The MIC of the control strain (A. flavus ATCC 204304) was within the range provided by $\mathrm{CLSI}^{7}$.

When TRB was combined with KTZ, ITZ or VRZ, synergism was observed in one isolate $(2.2 \%)$ for TRB+ITZ and two for TRB+KTZ
(2.25\%). Additive interactions were observed for TRB+KTZ (26.7\% of isolates), TRB+ITZ (33.3\% of isolates) and TRB+VRZ (11.1\% of isolates). Most interactions were indifferent, as was the case for $\mathrm{TRB}+\mathrm{KTZ}(66.7 \%$ of isolates), TRB+ITZ (51.1\% of isolates) and $\mathrm{TRB}+\mathrm{VRZ}$ (51.1\% of isolates). Antagonism was observed only with one isolate when TRB was combined with KTZ, with four $(8.89 \%)$ isolates for the TRB+ITZ combination and with 17 (37.78\%) isolates for the $\mathrm{TRB}+\mathrm{VRZ}$ combination.

The enzymatic profiles of the Sporothrix spp., analyzed using the API ZYM ${ }^{\circledR}$, system are listed in Table 2. Based on the 11 substrates, the 36 isolates of Sporothrix schenckii tested could be categorized into 14 separate biotypes, from which $100 \%$ showed leucine arylamidase (LA) activity negative for $S$. schenckii isolates and $20 \%$ showed positive reactions for esterase (ES), esterase lipase (EL), alkaline phosphatase (KP), and naphtol-AS-BI-phosphohydrolase (NP). The non-schenckii species presented unique and very unusual features, as shown in Table 2. $S$. albicans and $S$. mexicana were the only strains with a positive reaction for leucine arylamidase (LA). The enzymatic activities of acid phosphatase (AP) and naphtol-AS-BI-phosphohydrolase (NP) were observed for all isolates studied and $\beta$-glucosidase (GS activity) was absent only for S. globosa and S. mexicana (Table 2).

\section{DISCUSSION}

To overcome antifungal resistance and toxicity from monotherapy with $\mathrm{AMB}$, antifungal combinations represent an alternative approach to enhance the efficacy of individual drugs and lower dosages; these combined drug treatments may result in reduced toxicity and therapeutic success in cases that do not respond to treatment with single antifungal agents ${ }^{12}$. High success rates for the treatment of sporotrichosis with ITZ alone $^{4}$ have not encouraged the use of antifungal combinations against Sporothrix spp. in the past few years. However, the recent description of Sporothrix complex species which are refractory to ITZ treatment has stimulated research for combined antifungal therapeutic alternatives to treat sporotrichosis i, $^{6,11,24}$.

The susceptibility tests for antifungal agents have not established break points for $S$. schenckii complex, albeit document M38-A2 (CLSI, 2008) suggests that for analytical purposes, a MIC $\geq 4.0 \mu \mathrm{g} / \mathrm{mL}$ for itraconazole may be considered resistant to some filamentous fungi ${ }^{17}$. Here all the $S$. schenckii and $S$. brasiliensis isolates were susceptible to ITZ (MIC range $0.03-0.5 \mu \mathrm{g} / \mathrm{mL}$ ). On the other hand, S. albicans, $S$. globosa and S. mexicana have shown high MICs to itraconazole, which have been demonstrated by some authors ${ }^{8,16,17,19}$.

Taking this fact into account, we evaluated the activity of TRB, the second choice for subcutaneous sporotrichosis treatment ${ }^{13}$, in association with ITZ, KTZ and VRZ. The TRB+KTZ and TRB+ITZ combinations produced indifferent and additive interactions for $97.5 \%$ and $87.5 \%$ of isolates, respectively. These data are in accordance with ZHANG et $a l .{ }^{24}$, who found predominantly additive and indifferent interactions with TRB+ITZ, highlighting the use of TRB alone or in combination with other antifungal agents in sporotrichosis cases that are not responsive to ITZ treatment.

We have also observed that VRZ demonstrated the highest MICs against Sporothrix spp. when compared to KTZ and ITZ. This reduced 
OLIVEIRA, D.C.; LORETO, E.S.; MARIO, D.A.N.; LOPES, P.G.M.; NEVES, L.V.; ROCHA, M.P.; SANTURIO, J.M. \& ALVES, S.H. - Sporothrix schenckii complex: susceptibilities to combined antifungal agents and characterization of enzymatic profiles. Rev. Inst. Med. Trop. Sao Paulo, 57(4): 289-94, 2015.

Table 1

In vitro susceptibility and interactions between terbinafine (TRB), itraconazole (ITZ), ketoconazole (KTZ), and voriconazole (VRZ) against clinical isolates of Sporothrix schenckii complex

\begin{tabular}{|c|c|c|c|c|c|c|c|c|c|c|c|c|c|}
\hline \multirow{2}{*}{ Isolate } & \multicolumn{4}{|c|}{$\mathrm{MIC}(\mu \mathrm{g} / \mathrm{mL})$} & \multicolumn{3}{|c|}{ MIC combination } & \multicolumn{3}{|c|}{ MIC combination } & \multicolumn{3}{|c|}{ MIC combination } \\
\hline & TRB & KTZ & ITZ & VRZ & TRB/KTZ & FICI & Int $^{1}$ & TRB/ITZ & FICI & Int $^{1}$ & TRB/VRZ & FICI & Int $^{1}$ \\
\hline SB01 & 0.25 & 0.5 & 0.25 & 8 & $0.125 / 0.25$ & 1.00 & $\mathrm{Ad}$ & $0.125 / 0.25$ & 1.50 & $\mathrm{I}$ & $0.5 / 0.5$ & 2.06 & $\mathrm{I}$ \\
\hline SB251 & 0.5 & 0.5 & 0.5 & 2 & $0.06 / 0.06$ & 0.25 & $\mathrm{~S}$ & $0.125 / 0.5$ & 1.25 & I & $1 / 0.06$ & 2.03 & $\mathrm{I}$ \\
\hline SB245 & 0.5 & 0.25 & 0.25 & 1 & $0.06 / 0.06$ & 0.37 & $S$ & $0.06 / 0.06$ & 0.37 & S & $0.5 / 0.125$ & 0.75 & Ad \\
\hline FMR8314 & 0.06 & 0.125 & 0.125 & 4 & $0.06 / 0.06$ & 1.54 & I & $0.06 / 0.125$ & 2.04 & I & $0.015 / 2$ & 0.76 & Ad \\
\hline FMR8319 & 0.06 & 0.06 & 0.25 & 1 & $0.06 / 0.125$ & 3.12 & I & $0.03 / 0.5$ & 2.04 & I & $0.06 / 1$ & 2.04 & $\mathrm{I}$ \\
\hline FMR8326 & 0.125 & 0.25 & 0.125 & 4 & $0.06 / 0.125$ & 1.00 & Ad & $0.06 / 0.06$ & 0.96 & $\mathrm{Ad}$ & $0.06 / 0.25$ & 0.56 & Ad \\
\hline SS02 & 0.25 & 0.25 & 0.125 & 8 & $0.125 / 0.125$ & 1.00 & Ad & $0.03 / 0.125$ & 1.12 & I & $0.25 / 0.25$ & 1.03 & $\mathrm{I}$ \\
\hline SS03 & 0.125 & 0.25 & 0.125 & 2 & $0.125 / 0.25$ & 2.00 & I & $0.016 / 0.125$ & 1.12 & I & $0.25 / 0.25$ & 3.0 & I \\
\hline SS04 & 0.06 & 0.125 & 0.125 & 4 & $0.125 / 0.03$ & 2.33 & I & $0.125 / 0.25$ & 2.0 & I & $0.25 / 0.25$ & 4.23 & A \\
\hline SS05 & 0.25 & 0.25 & 0.125 & 8 & $0.125 / 0.25$ & 1.50 & I & $0.125 / 0.25$ & 2.0 & I & $0.5 / 0.5$ & 2.06 & $\mathrm{I}$ \\
\hline SS06 & 0.03 & 0.5 & 0.5 & 4 & $0.016 / 0.5$ & 1.52 & I & $0.016 / 0.125$ & 0.77 & Ad & $0.25 / 0.25$ & 8.36 & A \\
\hline SS07 & 0.125 & 0.25 & 0.25 & 4 & $0.125 / 0.25$ & 2.00 & I & $0.016 / 0.125$ & 0.62 & Ad & $0.5 / 0.5$ & 4.12 & $\mathrm{~A}$ \\
\hline SS08 & 0.25 & 0.5 & 0.25 & 8 & $0.125 / 0.25$ & 1.00 & $\mathrm{Ad}$ & $0.125 / 0.25$ & 2.0 & I & $0.25 / 0.125$ & 1.02 & I \\
\hline SS09 & 0.06 & 0.25 & 0.125 & 8 & $0.125 / 0.25$ & 3.08 & $\mathrm{I}$ & $0.125 / 0.125$ & 3.08 & I & $0.25 / 0.125$ & 4.18 & A \\
\hline SS10 & 0.125 & 0.125 & 0.03 & 4 & $0.125 / 0.25$ & 2.00 & I & $0.125 / 0.25$ & 2.0 & I & $0.25 / 0.25$ & 2.06 & I \\
\hline SS11 & 0.03 & 0.125 & 0.125 & 8 & $0.016 / 0.5$ & 4.52 & $\mathrm{~A}$ & $0.016 / 0.125$ & 1.52 & I & $0.25 / 0.25$ & 8.36 & A \\
\hline SS12 & 0.25 & 0.5 & 0.5 & 8 & $0.125 / 0.125$ & 0.75 & $\mathrm{Ad}$ & $0.016 / 0.125$ & 0.31 & S & $0.25 / 0.25$ & 1.03 & I \\
\hline SS13 & 0.25 & 0.06 & 0.03 & 1 & $0.25 / 0.016$ & 1.26 & I & $0.5 / 0.016$ & 2.52 & I & $1.0 / 0.016$ & 4.01 & A \\
\hline SS14 & 0.06 & 0.25 & 0.25 & 8 & $0.125 / 0.25$ & 3.00 & I & $0.016 / 0.125$ & 0.76 & Ad & $1.0 / 0.25$ & 16.7 & A \\
\hline SS15 & 0.125 & 0.125 & 0.125 & 4 & $0.125 / 0.25$ & 3.00 & I & $0.25 / 1.0$ & 10.0 & $\mathrm{~A}$ & $1.0 / 0.5$ & 8.13 & A \\
\hline SS16 & 0.25 & 0.5 & 0.25 & 8 & $0.125 / 0.125$ & 0.75 & Ad & $0.016 / 0.125$ & 0.56 & Ad & $0.25 / 0.125$ & 1.02 & I \\
\hline SS17 & 0.125 & 0.125 & 0.125 & 16 & $0.125 / 0.125$ & 2.00 & I & $0.016 / 0.125$ & 1.13 & I & $0.25 / 0.125$ & 2.00 & I \\
\hline SS18 & 0.03 & 0.5 & 0.25 & 4 & $0.016 / 1.0$ & 2.52 & I & $0.016 / 0.125$ & 1.02 & I & $0.25 / 0.125$ & 8.36 & A \\
\hline SS19 & 0.125 & 2 & 0.5 & 16 & $0.016 / 1.0$ & 0.62 & $\mathrm{Ad}$ & $0.06 / 0.125$ & 0.75 & Ad & $0.25 / 0.25$ & 2.01 & $\mathrm{I}$ \\
\hline SS20 & 0.25 & 0.25 & 0.125 & 8 & $0.125 / 0.25$ & 1.50 & I & $0.125 / 0.25$ & 2.5 & I & $1.0 / 0.5$ & 4.06 & A \\
\hline SS21 & 0.125 & 0.5 & 0.25 & 16 & $0.125 / 0.25$ & 1.50 & I & $0.031 / 0.25$ & 1.25 & I & $0.25 / 0.125$ & 2.0 & $\mathrm{I}$ \\
\hline SS22 & 0.06 & 0.25 & 0.125 & 4 & $0.125 / 0.25$ & 3.08 & I & $0.016 / 0.5$ & 4.26 & A & $2.0 / 0.016$ & 33.3 & A \\
\hline $\mathrm{SS} 23$ & 0.125 & 0.25 & 0.5 & 8 & $0.125 / 0.25$ & 2.00 & I & $0.016 / 0.25$ & 0.62 & Ad & $0.25 / 0.25$ & 2.03 & I \\
\hline SS24 & 0.25 & 0.125 & 0.25 & 4 & $0.5 / 0.016$ & 2.12 & I & $0.125 / 0.016$ & 0.56 & $\mathrm{Ad}$ & $0.25 / 0.125$ & 1.03 & I \\
\hline SS25 & 0.06 & 0.5 & 0.25 & 4 & $0.125 / 0.25$ & 2.58 & I & $0.125 / 0.25$ & 3.08 & I & $0.25 / 0.125$ & 4.20 & A \\
\hline SS26 & 0.06 & 1 & 0.25 & 4 & $0.016 / 0.5$ & 0.76 & Ad & $0.016 / 0.125$ & 0.76 & Ad & $0.25 / 0.125$ & 4.20 & A \\
\hline SS27 & 0.125 & 0.5 & 0.25 & 8 & $0.125 / 0.25$ & 1.50 & I & $0.125 / 0.25$ & 2.00 & I & $0.25 / 0.125$ & 2.02 & I \\
\hline $\mathrm{SS} 28$ & 0.125 & 0.25 & 0.25 & 4 & $0.125 / 0.25$ & 2.00 & I & $0.016 / 0.125$ & 0.62 & Ad & $0.5 / 1.0$ & 4.25 & A \\
\hline SS29 & 0.06 & 0.5 & 0.125 & 4 & $0.016 / 1.0$ & 2.26 & I & $0.125 / 0.25$ & 4.08 & A & $0.25 / 0.25$ & 4.23 & A \\
\hline SS33 & 0.25 & 2 & 1 & 16 & $0.125 / 0.25$ & 0.63 & Ad & $0.125 / 0.25$ & 0.75 & Ad & $0.25 / 0.125$ & 1.01 & I \\
\hline SS34 & 0.125 & 0.5 & 1 & 4 & $0.125 / 0.25$ & 1.50 & I & $0.016 / 1.0$ & 1.12 & I & $0.5 / 0.03$ & 4.01 & A \\
\hline SS35 & 0.125 & 0.5 & 0.5 & 8 & $0.125 / 0.25$ & 1.50 & I & $0.125 / 0.25$ & 1.50 & I & $0.25 / 0.125$ & 2.02 & I \\
\hline SS36 & 0.125 & 0.5 & 0.5 & 8 & 0.1250 .25 & 1.50 & I & $0.016 / 0.25$ & 0.62 & Ad & $0.25 / 0.125$ & 2.02 & I \\
\hline SS37 & 0.125 & 0.25 & 0.5 & 16 & $0.125 / 0.25$ & 2.00 & I & $0.016 / 0.25$ & 1.13 & I & $0.25 / 0.125$ & 2.02 & I \\
\hline SS38 & 0.125 & 2 & 1 & 8 & $0.125 / 0.25$ & 1.13 & I & $0.5 / 0.5$ & 1.0 & Ad & $0.25 / 0.125$ & 2.02 & I \\
\hline SS39 & 0.25 & 0.5 & 0.5 & 8 & $0.125 / 0.25$ & 1.00 & $\mathrm{Ad}$ & $0.125 / 0.25$ & 1.00 & Ad & $1 / 0.016$ & 4.01 & A \\
\hline SS40 & 0.125 & 0.25 & 0.03 & 8 & $0.125 / 0.25$ & 2.00 & I & $1.0 / 0.016$ & 8.52 & A & $0.25 / 0.125$ & 2.02 & I \\
\hline SA32 & 0.25 & 4 & $>128$ & 8 & $0.125 / 0.25$ & 0.56 & $\mathrm{Ad}$ & $0.5 / 2.0$ & 2.0 & I & $0.125 / 1.0$ & 0.63 & Ad \\
\hline SG00 & 0.25 & 2 & 8 & 16 & $0.25 / 0.5$ & 1.25 & I & $0.125 / 1.0$ & 0.625 & A & $0.25 / 8.0$ & 1.5 & I \\
\hline SM00 & 0.25 & 4 & 32 & 16 & $0.03 / 4$ & 1.0 & Ad & $0.125 / 4.0$ & 0.625 & $\mathrm{~A}$ & $0.125 / 8.0$ & 1.0 & $\mathrm{Ad}$ \\
\hline
\end{tabular}


OLIVEIRA, D.C.; LORETO, E.S.; MARIO, D.A.N.; LOPES, P.G.M.; NEVES, L.V.; ROCHA, M.P.; SANTURIO, J.M. \& ALVES, S.H. - Sporothrix schenckii complex: susceptibilities to combined antifungal agents and characterization of enzymatic profiles. Rev. Inst. Med. Trop. Sao Paulo, 57(4): 289-94, 2015.

Table 2

Enzymatic profile of clinical isolates of Sporothrix schenckii (SS), Sporothrix brasiliensis (SB), Sporothrix albicans (SL),

Sporothrix globosa (SG) and Sporothrix mexicana (SM)

\begin{tabular}{|c|c|c|c|c|c|c|c|c|c|c|c|c|}
\hline \multirow{2}{*}{ Species } & \multicolumn{11}{|c|}{ Strains showing activity for: } & \multirow{2}{*}{$\begin{array}{c}\text { Number of isolates } \\
(\%)\end{array}$} \\
\hline & $\mathrm{KP}$ & ES & EL & LP & LA & AP & NP & GC & GS & NG & $\mathrm{MN}$ & \\
\hline SB & + & + & + & - & - & + & + & - & + & + & - & $1(2.2)$ \\
\hline SB & + & + & - & - & - & + & + & + & + & - & - & $1(2.2)$ \\
\hline SB & + & + & + & - & - & + & + & + & + & + & + & $1(2.2)$ \\
\hline SB & + & - & - & - & - & + & + & - & + & - & - & $2(4.4)$ \\
\hline SB & + & - & - & - & - & + & + & - & + & - & + & $1(2.2)$ \\
\hline SS & + & + & + & - & - & + & + & - & + & + & - & $2(4.4)$ \\
\hline SS & - & + & + & - & - & + & + & + & + & - & - & $3(6.6)$ \\
\hline SS & - & + & + & - & - & + & + & - & + & - & - & $14(31.1)$ \\
\hline SS & + & + & + & - & - & + & + & - & + & + & + & $1(2.2)$ \\
\hline SS & + & + & + & - & - & + & + & + & + & + & + & $1(2.2)$ \\
\hline SS & + & + & - & - & - & + & + & - & + & - & - & $1(2.2)$ \\
\hline SS & - & - & + & - & - & + & + & - & + & - & - & $2(4.4)$ \\
\hline SS & + & + & + & - & - & + & + & - & + & - & - & $3(6.6)$ \\
\hline SS & + & + & + & - & - & + & + & + & + & - & - & $1(2.2)$ \\
\hline SS & - & - & - & - & - & + & + & - & + & - & - & $1(2.2)$ \\
\hline SS & - & + & - & - & - & + & + & - & + & - & - & $2(4.4)$ \\
\hline SS & - & + & + & - & - & + & + & - & + & + & - & $3(6.6)$ \\
\hline SS & - & - & - & - & - & + & + & - & + & + & - & $1(2.2)$ \\
\hline SS & - & + & - & - & - & + & + & + & + & - & - & $1(2.2)$ \\
\hline SA & - & + & + & - & + & + & + & - & + & - & - & $1(2.2$ \\
\hline SG & - & + & + & - & - & + & + & - & - & - & - & $1(2.2$ \\
\hline SM & + & + & + & - & + & + & + & - & - & - & - & $1(2.2)$ \\
\hline TOTAL & 16 & 38 & 35 & 0 & 3 & 45 & 45 & 8 & 43 & 10 & 4 & \\
\hline
\end{tabular}

${ }^{a}$ Substrates for enzymes: alkaline phosphatase (KP); esterase (ES); esterase lipase (EL); lipase (LP); leucine arylamidase (LA); acid phosphatase (AP); naphthol-ASBI-phosphohydrolase (NP); $\alpha$-glucosidase (GC); $\beta$-glucosidase (GS); $N$-acetyl- $\beta$-glucosaminidase (NG); $\alpha$-mannosidase (MN).

susceptibility has been previously described ${ }^{1,16,17}$, and the TRB+VRZ combination employed here predominantly showed indifferent $(55 \%)$ and antagonistic (42\%) interactions. Thus, the use of VRZ alone or in combination with TRB in sporotrichosis treatment does not appear to be advantageous.

Importantly, there are no protocols describing the use (or not) of the classification of additive in drug synergism testing for fungi, which is often subject of discussion and misunderstanding. Mathematically, additive is logical for the classical Loewe additivity model, as discussed by JOHNSON et al..$^{12}$, and it was used in this study didactically. The terms additive and indifferent are both related to the neutral nature of drugs interaction, i.e. neither synergistic nor antagonistic interactions. However, biological differences that can be observed between these interpretations are multifactorial.
Several studies have demonstrated the ability of fungi to produce extracellular enzymes such as proteases, lipases, keratinases and others, which represents a useful tool to identify microorganisms and thus providing an understanding of the relationships between enzyme production and pathogenicity. The use of the API ZYM ${ }^{\circledR}$ system to study the enzymatic profiles of different fungal species was previously reported ${ }^{14,23}$. The Api Zym ${ }^{\circledR}$ detection system was considered as a suitable option for the characterization of $S$. schenckii species complex as a result of presenting well-defined profiles.

Our results have demonstrated high intraspecific variability for the enzymatic activity of $S$. schenckii strains and revealed the presence of 14 different biotypes. The main biotype ( $35 \%$ of $S$. schenckii) demonstrated ES, EL, AP, NP activities, and these enzymatic activities were also observed for all the species studied. We believe these enzymes could 
OLIVEIRA, D.C.; LORETO, E.S.; MARIO, D.A.N.; LOPES, P.G.M.; NEVES, L.V.; ROCHA, M.P.; SANTURIO, J.M. \& ALVES, S.H. - Sporothrix schenckii complex: susceptibilities to combined antifungal agents and characterization of enzymatic profiles. Rev. Inst. Med. Trop. Sao Paulo, 57(4): 289-94, 2015.

be associated with virulence factors required for the development of sporotrichosis and so, deserve further investigation.

Differential identification of the Sporothrix complex by phenotype is based on the size of radial colony growth, the morphology of conidia, the assimilation of sucrose and raffinose, and the ability to grow at $37{ }^{\circ} \mathrm{C}^{15,16}$. Our results bring new contributions to the phenotypic identification of species enrolled in the S. schenckii complex based on the pattern of enzymatic activities. Thus, as expected, we must emphasize the following profiles: i) $S$. albicans and $S$. mexicana were the only ones to show LA activity and ii) S. globosa and S. mexicana were the only species showing absent GS activity. Further studies with a larger number of non-schenckii species are required in order to detect intraspecific variability. Even so, our results will be helpful when associated with the phenotypic tests recommended by MARIMON et $a l .{ }^{15}$, rendering the phenotypic tests more effective in order to identify cryptic species of the Sporothrix complex.

In conclusion, the in vitro combinations of TRB with KTZ and TRB with ITZ were shown to be advantageous compared to the use of these drugs individually, but antagonism was common with the TRB+VRZ combination. The enzymatic screening data represent an addition to the available methods for phenotypic characterization of new Sporothrix schenckii complex species, as well as an interesting area for further research to identify and explore the virulence of the Sporothrix complex.

\section{RESUMO}

\section{Complexo Sporothrix schenckii: susceptibilidade à combinação de antifúngicos e caracterização dos perfis enzimáticos}

Avaliou-se a susceptibilidade de Sporothrix albicans $(\mathrm{n}=1), S$. brasiliensis $(\mathrm{n}=1)$, S. globosa $(\mathrm{n}=1)$, S. mexicana $(\mathrm{n}=1)$ e $S$. schenckii $(\mathrm{n}=36)$ frente à terbinafina $(\mathrm{TRB})$ e a TRB em combinação com itraconazol (ITZ), cetoconazol (KTZ) e voriconazol (VRZ) pelo método de microdiluição (checkerboard); o perfil enzimático destas espécies foi também avaliado, com base no kit API-ZYM. A maioria das interações foram aditivas $(27,5 \%, 32,5 \%$ e $5 \%)$ ou indiferentes $(70 \%, 50 \%$ e $52,5 \%)$ para TRB+KTZ, TRB+ITZe TRB+VRZ, respectivamente. Antagonismo foi observado em $42,5 \%$ dos isolados para a combinação TRB+VRZ. Com base nos perfis enzimáticos, as cepas de Sporothrix schenckii evidenciaram 14 biotipos distintos. A atividade da leucina arilamidase (LA) só foi observada em $S$. albicans e $S$. mexicana. As espécies $S$. globosa e $S$. mexicana foram as únicas que não evidenciaram atividade da enzima $\beta$-glucosidase (GS). Estes resultados poderão contribuir para um melhor entendimento da virulência e resistência entre as espécies do gênero Sporothrix em futuros estudos.

\section{ACKNOWLEDGMENTS}

We thank Prof. Dr. Zoilo P. Camargo and Dr. Anderson M. Rodrigues from UNIFESP (Brazil) for kindly supplying us with some strains. We would also like to thank the Brazilian agency CAPES for their support. Loreto E.S. is the recipient of a PNPD-CAPES fellowship. Mario D.A.N. thanks the Fundação de Amparo à Pesquisa do Estado do Rio Grande do Sul (FAPERGS) for grant support and Alves S.H. thanks the financial support provided by $C N P q$ (Grant Proc. 470229/2012-8).

\section{REFERENCES}

1. Alvarado-Ramirez E, Torres-Rodriguez JM. In vitro susceptibility of Sporothrix schenckii to six antifungal agents determined using three different methods. Antimicrob Agents Chemother. 2007;51:2420-3.

2. Alves SH, Boettcher CS, Oliveira DC, Tronco-Alves GR, Sgaria MA, Thadeu P, et al. Sporothrix schenckii associated with armadillo hunting in Southern Brazil: epidemiological and antifungal susceptibility profiles. Rev Soc Bras Med Trop. 2010;43:523-5

3. Arrillaga-Moncrieff I, Capilla J, Mayayo E, Marimon R, Marinéé M, Genéé J, et al. Different virulence levels of the species of Sporothrix in a murine model. Clin Microbiol Infect. 2009; 15:651-5.

4. Barros MBD, Schubach AO, de Oliveira RVC, Martins EB, Teixeira JL, Wanke B. Treatment of cutaneous sporotrichosis with itraconazole-study of 645 patients. Clin Infect Dis. 2011;52:e200-e6.

5. Barros MBL, Paes RA, Schubach AO. Sporothrix schenckii and sporotrichosis. Clin Microbiol Rev. 2011;24:633-54.

6. Bunce PE, Yang L, Chun S, Zhang SX, Trinkaus MA, Matukas LM. Disseminated sporotrichosis in a patient with hairy cell leukemia treated with amphotericin B and posaconazole. Med Mycol. 2012;50:197-201.

7. Clinical and Laboratory Standards Institute. Reference method for broth dilution antifungal susceptibility testing of filamentous fungi: approved standard. $2^{\text {nd }}$ ed. Wayne: CLSI/M38-A2; 2008.

8. Dias NM, Oliveira MME, Santos C, Zancopé-Oliveira RM, Lima N. Sporotrichosis caused by Sporothrix mexicana, Portugal. Emerg Infect Dis. 2011;17:1975-6.

9. Francesconi G, Francesconi do Valle AC, Passos SL, de Lima Barros MB, de Almeida Paes R, Curi AL, et al. Comparative study of $250 \mathrm{mg} /$ day terbinafine and $100 \mathrm{mg} /$ day itraconazole for the treatment of cutaneous sporotrichosis. Mycopathologia. 2011;171:349-54

10. Freitas DF, de Siqueira Hoagland B, do Valle AC, Fraga BB, de Barros MB, de Oliveira Schubach A, et al. Sporotrichosis in HIV-infected patients: report of 21 cases of endemic sporotrichosis in Rio de Janeiro, Brazil. Med Mycol. 2012;50:170-8.

11. Gremião IDF, Schubach TMP, Pereira SA, Rodrigues AM, Honse CO, Barros MBL. Treatment of refractory feline sporotrichosis with a combination of intralesional amphotericin B and oral itraconazole. Aust Vet J. 2011;89:346-51.

12. Johnson MD, MacDougall C, Ostrosky-Zeichner L, Perfect JR, Rex JH. Combination antifungal therapy. Antimicrob Agents Chemother. 2004;48:693-715.

13. Kauffman CA, Bustamante B, Chapman SW, Pappas PG. Clinical practice guidelines for the management of sporotrichosis: 2007 update by the Infectious Diseases Society of America. Clin Infect Dis. 2007;45:1255-65.

14. Leone R, Buonomo S, Nakamura K, Aoki S, Vidotto V. Enzymatic profile of Cryptococcus neoformans strains by using the API-ZYM system. Rev Iberoam Micol. 1998;15:136-40.

15. Marimon R, Cano J, Gené J, Sutton DA, Kawasaki M, Guarro J. Sporothrix brasiliensis, S. globosa, and S. mexicana, three new Sporothrix species of clinical interest. J Clin Microbiol. 2007;45:3198-206.

16. Marimon R, Serena C, Gen J, Cano J, Guarro J. In vitro antifungal susceptibilities of five species of Sporothrix. Antimicrob Agents Chemother. 2008;52:732-4.

17. Oliveira DC, Lopes PGM, Spader TB, Mahl CD, Tronco-Alves GR, Lara VM, et al. Antifungal susceptibilities of Sporothrix albicans, S. brasiliensis and S. luriei of the S. schenckii complex identified in Brazil. J Clin Microbiol. 2011;49:3047-9. 
OLIVEIRA, D.C.; LORETO, E.S.; MARIO, D.A.N.; LOPES, P.G.M.; NEVES, L.V.; ROCHA, M.P.; SANTURIO, J.M. \& ALVES, S.H. - Sporothrix schenckii complex: susceptibilities to combined antifungal agents and characterization of enzymatic profiles. Rev. Inst. Med. Trop. Sao Paulo, 57(4): 289-94, 2015.

18. Silveira CP, Torres-Rodriguez JM, Alvarado-Ramirez E, Murciano-Gonzalo F, Dolande M, Panizo M, et al. MICs and minimum fungicidal concentrations of amphotericin B, itraconazole, posaconazole and terbinafine in Sporothrix schenckii. J Med Microbiol. 2009;58:1607-10.

19. Stopiglia CD, Magagnin CM, Castrillón MR, Mendes SDC, Heidrich D, Valente P, et $a$ l. Antifungal susceptibilities and identification of species of the Sporothrix schenckii complex isolated in Brazil. Med Mycol. 2014;52:56-64.

20. Velasquez S, Bailey E, Jandourek A. Evaluation of the antifungal activity of amphotericin B in combination with fluconazole, itraconazole, voriconazole or posaconazole against Candida species using a checkerboard method. Clin Infect Dis. 2000;31:266

21. Xue SL, Li L. Oral potassium iodide for the treatment of sporotrichosis. Mycopathologia. 2009;167:355-6.

22. Yamada K, Zaitz C, Framil VMDS, Muramatu LH. Cutaneous sporotrichosis treatment with potassium iodide: a 24 year experience in São Paulo State, Brazil. Rev Inst Med Trop Sao Paulo. 2011;53:89-93.

23. Zanette RA, Ferreiro L, Alves SH, Jesus FPK, Lautert C, Spanamberg A, et al. Enzymatic variability among Brazilian Pythium insidiosum isolates. Rev Iberoam Mycol. 2013;30:264-6.

24. Zhang XH, Huang HQ, Feng PY, Zhang J, Zhong Y, Xue RZ, et al. In vitro activity of itraconazole in combination with terbinafine against clinical strains of itraconazoleinsensitive Sporothrix schenckii. Eur J Dermatol. 2011;21:573-6.

Received: 15 May 2014

Accepted: 7 November 2014 